\title{
Effect of Neem, Siam Weed and Vetiver Oils on Physiological Reactions and Fitness of House Fly, Musca domestica L
}

\author{
$1 *$ SOYELU, OJ; ${ }^{1}$ OLUWAMAKINDE, BA; ${ }^{2}$ OKONJI, RE \\ ${ }^{*}$ Department of Crop Production and Protection, Faculty of Agriculture, Obafemi Awolowo University, Ile-Ife 220005, Osun State, \\ Nigeria. \\ ${ }^{2}$ Department of Biochemistry and Molecular Biology, Faculty of Science, Obafemi Awolowo University, Ile-Ife 220005, Osun State, Nigeria. \\ *Corresponding Author Email: jlekan2001@yahoo.co.uk; soyelu@oauife.edu.ng
}

\begin{abstract}
Insecticidal activities of hexane extracts of leaves and roots of siam weed and vetiver, and roots of neem were assessed against house fly, Musca domestica L. Mortality test was conducted using serial concentrations $20 \%$, $10 \%, 5 \%$ and $2.5 \%$ of extracted oils while behavioural orientation of house fly to oil odour, antioviposition effect of oil toward the insects, biochemical reactions in treated flies and fitness of offspring were determined using $20 \%$ oil concentration. House fly mortality varied significantly with plant species and part of plant extracted $(P<0.001)$, concentration applied $(P<0.001)$ and time post-exposure $(P<0.001)$. All tested plant extracts showed potential as good control agents with average mortality ranging from $59-74 \%$. However, significantly lower median lethal values $\left(\mathrm{LC}_{50}\right.$ and $\mathrm{LT}_{50}$ ) separated vetiver as the most toxic plant against the insect pest. The plant oils repelled house flies $(93-100 \%)$, reduced the number of larvae that hatched from laid eggs, lowered adult emergence and caused a significant reduction in size and weight of offspring. On the contrary, exposure to plant oils did not alter offspring sex ratio. In comparison to untreated house flies, plant oils induced biochemical stress in poisoned cohorts as evidenced in significant deviation of digestive enzyme ( $\alpha$ - and $\beta$ - amylases, lipase) activity and concentrations of detoxifying enzyme (glutathione-Stransferase), neurochemical enzyme (acetylcholinesterase) and energy metabolism biomolecules (total protein). Implications of obtained results for non-chemical control strategies are discussed.
\end{abstract}

DOI: https://dx.doi.org/10.4314/jasem.v24i3.20

Copyright: Copyright $\mathbb{C} 2020$ Soyelu et al. This is an open access article distributed under the Creative Commons Attribution License (CCL), which permits unrestricted use, distribution, and reproduction in any medium, provided the original work is properly cited.

Dates: Received: 16 November 2019; Revised: 11 January 2020; Accepted: 22 February 2020

Keywords: Biochemical reactions, essential oils, house fly, offspring fitness

The house fly, Musca domestica L. (Diptera: Muscidae), is a cosmopolitan insect pest found in both urban and rural settings and capable of spreading widely, travelling as far as $20 \mathrm{~km}$ within $24 \mathrm{~h}$ in search of food. The insect pest is strongly believed to transmit at least 65 diseases of man and animals some of which are capable of causing very high mortality soon after infection (Blackburn et al., 2015). Disease transmission is aided by the natural habit of adult house flies to defecate and regurgitate on food items with the resulting ill-health taking a great toll on man, animal and global economy.

Synthetic chemical application in form of aerosol or bait is the main strategy for controlling house fly but overreliance on these pesticides or misuse of same has often been accompanied by adverse effects on man and his environment. House fly has also developed single- and multi-pesticide resistance (Acevedo et al., 2009) thus prompting some users to indulge in using higher-than-recommended dose rates. This act worsens pest situations in the ecosystem often leading to man and animal poisoning, and environmental pollution. The desire for a safe environment has increased interest in sourcing for cheap and friendly alternative control measures against house fly. Biological control strategies using pathogens and plant-based products provide more user- and environment-friendly alternatives to conventional chemical insecticides (Al-Olayan, 2013).

Plant oils vary in their modes of action but they generally alter functions of proteins in insect body. They can alter activities of digestive enzymes, transmission enzyme (acetylcholinesterase) and detoxifying proteins such as glutathione-Stransferases. Plant oils can also act by interfering with insect growth and development, behaviour and fitness (Moawad and Sadek, 2018). These changes have been attributed to the presence of alkaloids, steroids, anthraquinones, flavonoides, tannins, polyphenyls and terpenes in essential oils (EOs). The present study was, therefore, carried out to assess the bio-efficacy of five plant oils against house fly and identify a suitable extract that could be formulated into an effective botanical insecticide. 


\section{MATERIALS AND METHODS}

Preparation of plant samples and oil extraction: Fresh samples of neem (leaf), siam weed (leaf and root) and vetiver (leaf and root) were collected within Obafemi Awolowo University (OAU), Ile-Ife and air-dried on a shaded platform to prevent oil degradation by direct sunlight. Thereafter, $800 \mathrm{~g}$ of each plant material was milled mechanically into fine powder and volatile oil was extracted by distillation using n-hexane in a Clevenger apparatus. Water in extracted oils was removed using $\mathrm{Na}_{2} \mathrm{SO}_{4}$ and the five extracts were kept in a fridge until they were needed for experiments. Oil extraction was carried out at the Drug Research and Production Unit, Faculty of Pharmacy, OAU, Ile-Ife.

Establishment of house fly colony: Adult house flies were collected from dumpsites within OAU, Ile-Ife and reared in the laboratory as described by Abulude et al. (2019). Newly emerged ( $\leq 3 \mathrm{~d}) 4^{\text {th }}$ generation adult flies were used for experiments to ensure a stock free from influences of the wild.

Mortality test: Serial dilutions 20\%, 10\%, 5\% and $2.5 \%$ were made from each stock solution of extracted plant oils and $2 \mathrm{ml}$ of each dilution was added to $2 \mathrm{~g}$ granulated sugar in triplicate. The treated diet (in Petri dishes) was air-dried for the solvent (n-hexane) to evaporate completely before they were put inside separate $30 \mathrm{~cm} \times 30 \mathrm{~cm} \times 30 \mathrm{~cm}$ experimental cages. Ten adult house flies were introduced into each cage and provision of water was delayed for about $18 \mathrm{~h}$ to create a no choice situation and ensure that flies fed on treated diet. Each cage was monitored and mortality was recorded on daily basis for seven days. Control experiment (i.e. diet treated with n-hexane) was also set up for comparison of results.

Repellency test: Granulated sugar was mixed in separate Petri dishes with $20 \%$ of each oil extract as described for mortality test and placed in separate cages; a dish without plant extract served as control in each cage. Thirty adult house flies that had been starved for at least $6 \mathrm{~h}$ were introduced into each cage and the number of flies found on each Petri dish $3 \mathrm{~min}$ after introduction was recorded. Each test was replicated ten times and percent repellency for a plant oil was determined as:

$$
\% \text { Repel }=\frac{\mathrm{NF}}{\mathrm{TNF}} \times 100
$$

Where: \% Repel $=$ Percentage repellency; NF = number of house flies on control Petri dish; TNF $=$ Total number of house flies tested per trial
Anti-oviposition and offspring fitness tests: A $70 \mathrm{~g}$ paste of the larval diet was mixed with $2 \mathrm{ml} 20 \%$ of each plant oil in separate Petri dishes. After air-drying, the dishes were placed in separate cages to serve as oviposition substrates. Each cage had artificial diet with similar treatment in three Petri dishes and untreated diet was provided in a similar manner in separate cages. Each treatment cage was replicated thrice. Twenty naïve, but mated, female flies were introduced into each cage and allowed to oviposit for $48 \mathrm{~h}$ after which they were removed carefully. In order not to destroy the delicate eggs, emerged larvae in each Petri dish were counted as a measure of number of eggs laid per treatment. The contents of the Petri dishes were monitored on daily basis, pupae were picked and kept in labelled dishes and adult emergence per oviposition substrate was determined as:

$$
\% \mathrm{AE}=\frac{\mathrm{NAT}}{\mathrm{TNL}} \times 100
$$

Where $\% \mathrm{AE}=$ adult emergence; $\mathrm{NAT}=$ number of eclosed adult per treatment; TNL $=$ Total number of larvae per treatment

Body weight $(\mathrm{mg})$, size $(\mathrm{mm})$ and sex ratio of resulting progeny were determined as indices of offspring fitness. Body weight of each adult house fly was determined using a sensitive balance while the length of forewing was taken as index of body size (Fartyal et al., 2017).

Preparation of tissue extract: A mixture of granulated sugar and $20 \%$ plant oil was placed in five cages; a cage for one of five tested oils. The control cages had only granulated sugar without plant oils. Eighty adult flies were introduced into each cage and they were provided with water $20 \mathrm{~h}$ after exposure for just $1 \mathrm{~h}$. This was to ensure that the flies did not choose water as an option for survival. The experiment was terminated after $36 \mathrm{~h}$ by lowering each cage into a deep-freezer; the flies were collected, weighed and homogenized in phosphate buffer $\mathrm{pH}$ 7.2. The supernatant for each treatment was collected after centrifuging at $4,000 \mathrm{rpm}$ for $30 \mathrm{~min}$ at $4^{\circ} \mathrm{C}$.

Biochemical assays: The total protein in each extract was determined according to the method of Bradford (1976) while $\alpha$ - and $\beta$-amylases as well as lipase were assayed as described by Oyebanji et al. (2014). Glutathione-S-transferase activity was determined following Vontas et al. (2000) and acetylcholinesterase activity was quantified as outlined by Ellman et al. (1961). 
Statistical analysis: Percent mortality and repellency data were square root-transformed while number of emerging larvae in anti-oviposition trials were natural log-transformed before being subjected to analysis of variance (ANOVA) using SAS v. 9.0. Fitness data for body size and weight of offspring, and enzyme concentrations were also subjected to ANOVA. Mean values were separated among treatments using the Tukey's HSD test at $\alpha=0.05$. Contribution of a source of variation to outcome of a particular event in adult house flies was calculated as:

$$
\text { contribution to an event }=\frac{\mathrm{SS}_{\mathrm{SV}}}{\mathrm{SS}_{\mathrm{T}}} \times 100 \%
$$

Where $\mathrm{SS}_{\mathrm{SV}}$ and $\mathrm{SS}_{\mathrm{T}}$ are sum of square values for a given experimental factor and the whole model, respectively. The median lethal concentration $\left(\mathrm{LC}_{50}\right)$ and lethal time $\left(\mathrm{LT}_{50}\right)$ were determined from mortality data using the predictive function of Microsoft ${ }^{\circledR}$ Office Excel.

\section{RESULTS AND DISCUSSION}

Mortality test: Analysis of variance (Table 1) showed that house fly mortality varied significantly $(P<$ 0.0001 ) with source of plant oil, concentration applied and time post-application. However, source of oil was the most important factor, contributing $31 \%$ of the variation in mortality followed by concentration of oil $(24 \%)$ and time after application (3\%). Generally, house fly mortality was concentration- and exposure time-dependent. Percent house fly mortality caused by essential oils of vetiver (leaf and root) and siam root was comparable but significantly higher than that from leaves of neem and siam weed (Table 2). However, the significantly lower $\mathrm{LC}_{50}$ and $\mathrm{LT}_{50}$ values showed that vetiver had the most potent essential oils. Comparison of results from earlier studies e.g., Ayvaz et al. (2010) showed that among other factors, insecticidal efficacy of EOs depends on the plant or part of plant from which the EO was extracted. Although vetiver grows in Nigeria, it is not as common as the other plants used in this study and little is known about its use as botanical insecticide in this locality.

Table 1: Analysis of variance showing effect of five plant oils, their concentrations and time post-exposure on survivability of adult house

\begin{tabular}{llllll}
\hline $\begin{array}{l}\text { Source of } \\
\text { variation }\end{array}$ & $\boldsymbol{d} \boldsymbol{f}$ & $\begin{array}{l}\text { Sum of } \\
\text { squares }\end{array}$ & $\begin{array}{l}\text { Mean } \\
\text { square }\end{array}$ & $\begin{array}{l}\text { F } \\
\text { value }\end{array}$ & $\begin{array}{l}\text { Percent contribution } \\
\text { to house fly mortality }\end{array}$ \\
\hline Source of EO & 5 & 303799.52 & $60759.90^{* * *}$ & 92.16 & 31.05 \\
Conc. of EO & 4 & 236003.81 & $59000.95^{* * *}$ & 89.49 & 24.12 \\
No. of days & 6 & 33718.73 & $5619.79^{* * *}$ & 8.52 & 3.45 \\
Replication & 2 & 1293.78 & 646.89 & 4.49 & 0.13 \\
Error & 612 & 403528.44 & 659.36 & & 41.25 \\
Total & 629 & 978344.29 & & \\
\hline \multicolumn{5}{c}{$* * * P<0.001 ;$ EO: Essential oil } \\
\end{tabular}

Table 2: Mortality of house flies and lethal indices of different plant oils provided in insect diet over a period of seven days

\begin{tabular}{|l|l|l|l|}
\hline \multirow{2}{*}{$\begin{array}{l}\text { Source of } \\
\text { essential oil }\end{array}$} & \multirow{2}{*}{$\begin{array}{l}\text { Percent house fly mortality } \\
\text { (minimum-maximum) }\end{array}$} & \multicolumn{3}{|c|}{ Median lethal values } \\
\cline { 3 - 4 } Neem leaf & $58.57 \mathrm{~b}(20.00-96.19)$ & $\mathbf{L C}_{\mathbf{5 0}} \mathbf{( \% )}$ & $\mathbf{L T}_{\mathbf{5 0}}$ (days) \\
\hline Siam leaf & $59.88 \mathrm{~b}(5.71-97.14)$ & $7.24 \pm 0.18 \mathrm{a}$ & $4.10 \pm 0.59 \mathrm{a}$ \\
\hline Vetiver leaf & $73.45 \mathrm{a}(19.52-99.52)$ & $6.01 \pm 0.03 \mathrm{~b}$ & $3.97 \pm 0.98 \mathrm{a}$ \\
\hline Siam root & $74.29 \mathrm{a}(70.48-78.57)$ & $6.54 \pm 0.96 \mathrm{a}$ & $2.35 \pm 0.27 \mathrm{c}$ \\
\hline Vetiver root & $74.05 \mathrm{a}(56.67-96.67)$ & $6.02 \pm 0.64 \mathrm{~b}$ & $1.14 \pm 0.13 \mathrm{c}$ \\
\hline Untreated & $0.48 \mathrm{c}(0.00-0.95)$ & & \\
\hline
\end{tabular}

Mean values within each column with different letters are significantly different at 0.05 level of probability. Median lethal values are expressed as mean $\pm S E$

Repellency, anti-oviposition and fitness tests: The five plant oils repelled adult flies effectively with efficacy of $93-100 \%$ (Table 3); an indication of strong repellents in the oils. Nootkatone, zizanol, bicyclovetivenol, tricyclic sesquiterpenoids, zizanal, epizizanal, $\alpha$-vetivone, $\beta$-vetivone, khusimone and (C)-(1S,10R)-1,10-dimethylbicyclo [4,4,0]-dec-6-en3 -one were reported as repellents in vetiver oil (Babprasert and Karintayakit, 1996) while azadirachtin and khusimone were reported in neem (Khanam et al., 2017) and siam (Joshi, 2013) oils, respectively. The repelling ability of these EOs would offer significant protection against house fly if applied in an endemic area such as the abattoir. The plant oils also affected offspring fitness adversely as evident in significantly lower number of hatched larvae, percent adult emergence, size and weight of newly eclosed adults. A lower number of hatched larvae on oilcontaining diet was an indication that the oils either showed anti-oviposition effect or they acted as ovicides. Neem oil was reported to have both ovicidal and oviposition deterrent activities against insects 
(Kala et al., 2019). Similarly, a reduced adult emergence signified reduced survivability (Habiba et al., 2019) while inability of house fly to utilize treated diet optimally resulted in reduced size and weight of new adults (Mikami and Ventura, 2008). Nevertheless, essential oils did not have any significant effect on sex ratio of emerging offspring; agreeing with the $1 q: 1 \sigma^{\lambda}$ stable ratio reported by Meisel et al. (2016) in samplings done 32 years apart.

\begin{tabular}{|c|c|c|c|c|c|c|}
\hline \multirow{2}{*}{$\begin{array}{l}\text { Source of } \\
\text { essential oil }\end{array}$} & \multirow{2}{*}{$\begin{array}{l}\text { Percent adult } \\
\text { repelled }\end{array}$} & \multicolumn{5}{|c|}{ Offspring performance } \\
\hline & & $\begin{array}{l}\text { Average larvae } \\
\text { per treatment }\end{array}$ & $\begin{array}{l}\text { Percent adult } \\
\text { emergence }\end{array}$ & $\begin{array}{l}\text { Percent female } \\
\text { offspring }\end{array}$ & $\begin{array}{l}\text { Body size } \\
(\mathrm{mm})\end{array}$ & $\begin{array}{l}\text { Body weight } \\
\text { (mg) }\end{array}$ \\
\hline Neem leaf & $93.33 \mathrm{a}$ & $75.02 \mathrm{c}$ & $68.47 \mathrm{~b}$ & $62.18 \mathrm{a}$ & $6.65 b$ & $6.69 \mathrm{~b}$ \\
\hline Siam leaf & $100.00 \mathrm{a}$ & $114.26 \mathrm{~b}$ & $73.95 b$ & $58.86 a$ & $6.63 b$ & $6.67 \mathrm{bc}$ \\
\hline Vetiver leaf & $95.56 \mathrm{a}$ & $38.14 d$ & $33.78 \mathrm{c}$ & $48.69 \mathrm{a}$ & $6.42 \mathrm{~cd}$ & $6.65 c$ \\
\hline Siam root & $95.56 \mathrm{a}$ & $107.32 b$ & $72.65 b$ & $40.04 \mathrm{a}$ & $6.57 \mathrm{bc}$ & $6.67 \mathrm{bc}$ \\
\hline Vetiver root & $98.89 \mathrm{a}$ & $69.11 \mathrm{c}$ & $39.26 \mathrm{c}$ & $50.07 \mathrm{a}$ & $6.50 \mathrm{c}$ & $6.66 \mathrm{bc}$ \\
\hline Untreated & $16.67 \mathrm{~b}$ & $208.78 \mathrm{a}$ & $96.27 \mathrm{a}$ & $49.17 \mathrm{a}$ & $7.33 \mathrm{a}$ & $10.00 \mathrm{a}$ \\
\hline
\end{tabular}

Mean values within each column with different letters are significantly different at 0.05 level of probability.

Enzyme activity: With the exception of vetiver leaf oil, activity of the two amylases was stimulated by EOs (Table 4) and this was attributed to ability of the oils to increase enzyme affinity for the substrates (Macedo et al., 2007). The EOs from siam and vetiver leaves reduced activity of the fly lipase but it was more severe in the latter. A significant enzyme inhibition or stimulation above the control would result in metabolic imbalance, growth impairment and house fly mortality (Babu and Subrahmanyam, 2010). The EOs from vetiver and siam root showed potential as nerve agents because they reduced activity of acetylcholinesterase significantly. The oils would interfere with activity of the enzyme at synaptic joints, hindering it from breaking down acetylcholine effectively and, thus, permitting perpetual transmission of impulses. This condition may

Table 4: Biochemical activity in adult house flies fed plant oil-containing artificial diet

\begin{tabular}{|l|l|l|l|l|l|l|}
\hline $\begin{array}{l}\text { Source of } \\
\text { essential oil }\end{array}$ & $\begin{array}{l}\boldsymbol{\alpha} \text {-amylase } \\
(\mathbf{m g} / \mathbf{m l} / \mathbf{m i n})\end{array}$ & $\begin{array}{l}\boldsymbol{\beta} \text {-amylase } \\
(\mathbf{m g} / \mathbf{m l} / \mathbf{m i n})\end{array}$ & $\begin{array}{l}\text { Lipase }\left(\times \mathbf{1 0}^{-\mathbf{5}}\right) \\
(\boldsymbol{\mu m o l} / \mathbf{m i n})\end{array}$ & $\begin{array}{l}\mathbf{A C h E} \\
(\boldsymbol{\mu m o l} / \mathbf{m i n})\end{array}$ & $\begin{array}{l}\text { GST } \\
(\boldsymbol{\mu m o l} / \mathbf{m i n})\end{array}$ & $\begin{array}{l}\text { Total protein } \\
(\mathbf{m g} / \mathbf{m l})\end{array}$ \\
\hline Neem leaf & $4170.4 \mathrm{a}$ & $4.1700 \mathrm{ab}$ & $7.649 \mathrm{a}$ & $65,813.00 \mathrm{~b}$ & $1916.730 \mathrm{c}$ & $2.9000 \mathrm{bc}$ \\
\hline Siam leaf & $4326.0 \mathrm{a}$ & $4.3267 \mathrm{a}$ & $3.654 \mathrm{~d}$ & $67,181.25 \mathrm{a}$ & $568.856 \mathrm{e}$ & $4.8670 \mathrm{a}$ \\
\hline Vetiver leaf & $3125.9 \mathrm{~b}$ & $3.4567 \mathrm{bc}$ & $2.800 \mathrm{e}$ & $45,731.25 \mathrm{e}$ & $565.474 \mathrm{e}$ & $3.5887 \mathrm{ab}$ \\
\hline Siam root & $4170.4 \mathrm{a}$ & $4.1700 \mathrm{ab}$ & $7.500 \mathrm{a}$ & $57,225.00 \mathrm{c}$ & $2874.504 \mathrm{~b}$ & $2.9333 \mathrm{bc}$ \\
\hline Vetiver root & $4000.0 \mathrm{a}$ & $4.0000 \mathrm{ab}$ & $6.920 \mathrm{~b}$ & $50,981.25 \mathrm{~d}$ & $1352.38 \mathrm{~d}$ & $2.0553 \mathrm{c}$ \\
\hline Untreated & $2970.4 \mathrm{~b}$ & $2.9700 \mathrm{c}$ & $4.980 \mathrm{c}$ & $65,206.25 \mathrm{~b}$ & $4130.49 \mathrm{a}$ & $2.2330 \mathrm{c}$ \\
\hline
\end{tabular}

Mean values within each column with different letters are significantly different at 0.05 level of probability. AChE: Acetylcholinesterase; GST: Glutathione-S-transferase
Conclusion: All the EOs tested showed potential as insecticidal agents against house fly with an appreciable level of adult mortality and excellent repellency. The reproductive success of the pest was significantly reduced by applied oils and the process of digestion was compromised. Similarly, the plant oils constitute potential threat to nervous and defense systems by inhibiting acetylcholinesterase and glutathione-S-transferase, respectively. Botanical insecticides are viable alternatives to synthetic chemicals and they create a safer environment. eventually lead to death of exposed insects. The neem oil did not have any significant effect on earlier reports e.g., Campos et al. (2016) which concluded that the oil acts basically as a growth regulator by inhibiting the ecdysone. All the EOs reduced efficacy of glutathione-S-transferase which is one of the defense proteins in house fly. This is an indication that the EOs may be a potential threat to the defense mechanism of house fly. The elevated total protein reported in flies treated with siam and vetiver leaf oils could be attributed to induced physiological stress which necessitated enhanced protein production to replenish depleted protein and ensure insect survival (Chou et al., 2012). acetylcholinesterase and this is in agreement with

\section{REFERENCES}

Abulude, IJ; Adio, IG; Ogunlola, F; Odejide, IT; Soyelu, OJ; Osoniyi, RO (2019). Effect of dietary lipid on biochemical activities and fitness of house fly, Musca domestica L. (Diptera: Muscidae). Int. J. Trop. Insect Sci. https://doi.org/10.1007/s42690019-00074-X

Acevedo, GR; Toloza, AC; Zapater, M (2009). Insecticide resistance of house fly, Muscadomestica (L.) from Argentina. Parasitol. Res. 105(2): 589593. 
Al-Olayan, EM (2013). Evaluation of pathogenicity of certain mitosporic ascomycete fungi to the house fly, Musca domestica L. (Diptera: Muscidae). J. Saudi Chem. Soc. 17: 97-100.

Ayvaz, A; Sagdic, O; Karaborklu, S; Ozturk I (2010). Insecticidal activity of the essential oils from different plants against three stored-product insects. J. Insect Sci. 10:21.

Babprasert, C; Karintayakit, P (1996). Vegetable pest management by using essential oil from vetiver grass (Vetiveria zizanioides Nash). Abstracts of papers presented at ICV-1, Chiang Rai, Thailand, p. 138.

Babu, SR; Subrahmanyam, B (2010). Bio-potency of serine proteinase inhibitors from Acacia senegal seeds on digestive proteinases, larval growth and development of Helicoverpa armigera (Hübner). Pest Biochem. Physiol. 98: 349-358.

Blackburn, JK; Odugbo, MO; van Ert, M; O’Shea, B; Mullins, J; Perreten, V; Maho, A; Hugh-Jones, M; Hadfield, T (2015). Bacillus anthracis diversity and geographic potential across Nigeria, Cameroon and Chad: Further support of a novel West African lineage. PLoSNegl. Trop. Dis. 9(8): e0003931. doi:10.1371/journal.pntd.0003931

Bradford, MM (1976). A rapid and sensitive method for the quantification of microgram quantities of protein, utilizing the principle of protein-dye binding. Anal. Biochem. 72: 248-254.

Campos, EVR; de Oliveira, JL; Pascoli, M; de Lima, R; Fraceto, LF (2016). Neem oil and crop protection: from now to the future. Front. Plant Sci. 7: 1494 doi:10.3389/fpls.2016.01494

Chou, CJ; Affolter, M; Kussmann, M (2012). A nutrigenomics view of protein intake: macronutrient, bioactive peptides, and protein turnover. Prog. Mol. Biol. Transl. Sci. 108: 51-74.

Ellman, GL; Courtney, KD; Andres Jr., V; Feather-Stone, RM (1961). A new and rapid colorimetric determination of acetylcholinesterase activity. Biochem. Pharmacol. 7(2): 88-95.

Fartyal, RS; Sarswat, M; Dewan, S; Fartyal, P (2017). Morphometric analysis of wild-caught flies of Drosophila (Diptera: Drosophilidae) species: Altitudinal pattern of body size traits, wing morphology and sexual dimorphism. Türk. Entomol. Derg. 41(4): 367-382.
Habiba, U; Islam, W; Parween, S (2019). Contact and gustatory effects of spinosad on the survivability of Sitophilus oryzae L. (Coleoptera: Curculionidae) in wheat. Bangladesh J. Zool. 47(1): 253-262.

Joshi, RK (2013). Chemical composition of the essential oil of Chromolaena odorata (L.) R.M. King \& H. Rob. roots from India. J. Chem. http://dx.doi.org/10.1155/2013/195057

Kala, S; Naik, SN; Patanjali, PK; Sogan N (2019). Neem oil water dispersible tablet as effective larvicide, ovicide and oviposition deterrent against Anopheles culicifacies. S. Afr. J. Biol. 123: 387-392.

Khanam, Z; Al-Yousef, HM; Singh, O; Bhat, IU (2017). Neem oil. In: Nollet LML; Rathore HS (eds.) Green Pesticides Handbook, CRC Press, New York, 570.

Macedo, MLR; Freire, MGM; Silva, MBR; Coelho, LCBB (2007). Insecticidal action of Bauhinia monandra leaf lectin (BmoLL) against Anagasta kuehniella (Lepidoptera: Pyralidae), Zabrotessub fasciatus and Callosobruchus maculatus (Coleoptera: Bruchidae). Comp. Biochem. Physiol. A 146:486-498.

Meisel, RP; Davey, T; Son, JH; Gerry, AC; Shono, T; Scott, JG (2016). Is multifactorial sex determination in the house fly, Musca domestica (L.), stable over time? J. Hered. 107(7): 615-625.

Mikami, A; Ventura, MU (2008). Repellent, antifeedant and insecticidal effects of neem oil on Microtheca punctigera. Braz. Arch. Biol. Technol. 51(6): 11211126.

Moawad, SS; Sadek, HE (2018). Evaluation of two ecofriendly botanical oils on cotton leaf worm, Spodoptera littoralis (Boisd) (Lep/Noctuidae). Ann. Agric. Sci. 63: 141-144.

Oyebanji, O; Soyelu, OJ; Bamigbade, A; Okonji, R (2014). Distribution of digestive enzymes in the gut of American cockroach, Periplaneta americana (L.). Int. J. Sci. Res. Publ. 4:1.

Vontas, JG; Enayati, AA; Small, GJ; Hemingway, J (2000). A simple biochemical assay for glutathioneS-transferase activity and its possible field application for screening glutathione-S-transferasebased insecticide resistance. Pestic. Biochem. Physiol. 68: 18 